\title{
The Effect of Closed Area on Woody Species Regeneration: A Case study in Loma Bosa Woreda, Dawuro zone, Southern Ethiopia
}

\author{
Assefa Ataro Ambushe \\ Ethiopia Ministry of Agriculture and Rural Development \\ Girma Gezimu Gebre ( $\sim$ girma.gezimu@gmail.com ) \\ Kyushu University https://orcid.org/0000-0003-4875-8825
}

Research article

Keywords: closed Area, Woody species, Regeneration, Open woodland, Open degraded land

Posted Date: July 30th, 2020

DOI: https://doi.org/10.21203/rs.3.rs-42801/v1

License: (a) (i) This work is licensed under a Creative Commons Attribution 4.0 International License. Read Full License 


\section{Abstract}

This study examines the effect of closed area on woody species regeneration by comparing the woody species regeneration among closure, open woodland, and degraded land areas in Loma Bosa district, Dawuro zone in southern Ethiopia. Results show that Simpson's Diversity Index was 7.24 for woody species in closed area, 6.01 in open woodland and 3.40 in open degraded land area. Shannon-Weiner Diversity Index $\left(H^{\prime}\right)$ was 2.26 for woody species in closed area, 2.38 in open woodland area and 1.56 in open degraded land area. The results of Sorenson's similarity coefficients indicates woody species composition in closed area are highly correlated with open woodland areas. Wood species density were $2,225 \mathrm{ha}^{-1}, 1,642 \mathrm{ha}^{-1}$, and $297 \mathrm{ha}^{-1}$ for closed area, open woodland area, and open degraded land area, respectively. The results indicate that closed area development enhanced species composition, richness, diversity, woody vegetation regeneration, inverted $J$ shape Diameter at Breast Height (DBH) and height class and higher woody species density and crown cover class percentage compared to open degraded area. Overall results from this study indicated that area closure is important for improvement of woody species regeneration in the study area.

\section{Introduction}

Land degradation, a process of diminishing the productive potentials of land resources, is one of the serious environmental problems at the global scale (Le et al., 2016; Nkonya et al., 2016). It has been increasing in severity and extent in many parts of the world. For instance, in 2008, the United Nations Food and Agriculture Organization (FAO) reported that more than $20 \%$ of all cultivated areas, $30 \%$ of forests, and $10 \%$ of grasslands undergoing degradation in the world. A recent study by Le et al. (2016) reported that about $29 \%$ of the global land area covered by the degraded land, which are affecting about 3.2 billion people who are especially rural communities, smallholder farmers, and the very poor in the developing regions of the world.

Land degradation mainly triggered by population pressure, expansion of agricultural land, deforestation, and over-exploitation of the natural resources (Mganga et al., 2015; Yirdaw et al., 2017, Manaye et al., 2019). It is one of the major drivers of declining agricultural productivity, increasing food insecurity, rural poverty, and deterioration of ecological functions in the world (Gashaw et al., 2018). Thus, combating of land degradation though rehabilitation and ecological restoration is important to ensure the long-term productivity of the land resources and survival of life on the earth (Asmare \& Gure, 2019; Manaye et al., 2019). Successful land rehabilitation and ecological restoration activities enhances improved land productivity, food security, livelihoods, biodiversity, ecological balance, and other ecosystem services and functions (Mureithi et al., 2014; Reside et al., 2017; Mekuria et al., 2017). Closuring degraded area from human and livestock interference is one of the successful rehabilitation activities to combat land degradation and its significant negative impacts on woody species generation in developing countries (Manaye et al., 2019).

In sub-Saharan Africa, land degradation is one of the biggest problems that threatening the lives of millions of people (Blay et al., 2004; Le et al., 2016; Nkonya et al., 2016). Like as other sub-Saharan African countries, land degradation is one the major problems in Ethiopia. It has been negatively affecting the agricultural production, livelihoods, and provision of other ecosystem goods and services in the country. The major causes of land degradation include extreme weather conditions particularly drought, high population pressure, severe

Loading [MathJax]/jax/output/CommonHTML/jax.js lons of the agricultural land, and inappropriate land-use systems

Page $2 / 29$ 
such as over-cultivation and mono cropping (Taddese, 2001; Gashaw et al., 2018; Megerssa \& Bekere, 2019). The major consequences of land degradation in Ethiopia include low or declining agricultural productivity, increase in food insecurity, loss of biodiversity, drying up of springs and water bodies, increased incidence of water-borne diseases, climate change, and desertification (Taddese, 2001; Abebe et al., 2014; Gashaw et al., 2018). The diagram in Fig. 1 summarizes the causes and consequences of land degradation that negatively affect the economy, environment and livelihoods of people in the country.

To combat the deforestation and land degradation problems, Ethiopia has initiated extensive number of rehabilitation programs, including establishment of closed areas and soil and water conservation activities. Particularly, the establishment of area closure considered an important tool to rehabilitate the degraded land, improve agricultural productivity, restore natural vegetation, reduce soil erosion, improve hydrological cycles and microclimate in the country (Betru et al., 2005; Mekuria et al., 2013; Teketay et al., 2018).

Following Betru et al. (2005), the operational definition of closed area in this study context is "the degraded communal land that has been excluded from livestock and human interference for rehabilitation". The main purposes of area closure in country is to improve agricultural productivity, restore vegetation, species composition, biomass, richness, diversity, and providing overall ecological functions to local communities (Kasim et al., 2015; Mekuria et al., 2018; Teketay et al., 2018). In principle, human and livestock interference is limited or completely restricted in closed areas to encourage rehabilitation of degraded lands and regeneration of natural vegetation in Ethiopia; however, several challenges are facing to make it fully realize. Because, in practice, in several places, local communities allow their livestock to free graze in the closed areas. Moreover, cutting grass and collection of fuel woods from dead trees are continued (Nedessa et al., 2005).

Therefore, despite government efforts to combat land degradation and deforestation, natural forests in Ethiopia are declining rapidly due to their conversion to arable lands coupled with inappropriate and excessive utilization triggered by increasing population growth (Senbeta et al., 2002). This situation has continued in the country. For instance, a report by FAO (2015) on Global Forest Resource Assessment (GFRA) indicates that the forest resource and other wooded land area change rate in the country is negative 104,000 ha per years since years 1990 to 2015. They suggest that the remaining high forests and biodiversity under threatened and will disappear within a few decades in the country. Hence, the major task facing Ethiopia includes protection and sustainable utilization of the remaining natural forests, expansion of tree plantation and restoration of degraded lands by establishing area closure in several parts of the country. Particularly, establishing area closure on degraded land is considered as a cheap and convenient means of rehabilitating degraded areas, and convenient for economically poor countries such as Ethiopia. Because in a closed area, rehabilitation of land or restoration of natural vegetation cover is primarily a natural process and human inputs are very limited to offering protection against interference. As a result, some call it 'zero management' strategy for rehabilitation of degraded land and restoration of natural vegetation. This process makes area closure economically the cheapest method of rehabilitation of degraded area (Teketay et al., 2018).

Now a day, closed area become very common and important tool to rehabilitate of degraded lands especially in the southern Ethiopia including Dawuro zone, Loma Bosa district because of the impressive changes in terms of ecological restoration, improve ecological succession, regeneration of different plant diversity, 
Therefore, this research is to examine the effect of closed area on woody species regeneration by comparing the woody species regeneration between closure, open woodland and degraded land area in the Zima Waruma kebele of Loma Bosa district in Dawuro zone, Southern Ethiopia.

\section{Materials And Methods}

\subsection{Description of study area}

The study area of this study is Loma Bosa district located in Dawuro zone of the Southern Nation Nationalities and Peoples Regional State (SNNPR) of Ethiopia. The geographical location of Loma Bosa district is between $6^{\circ} 42^{\prime} 13^{\prime \prime}-6^{\circ} 53^{\prime} 48^{\prime \prime} \mathrm{N}$ lat. and $37^{\circ} 00^{\prime} 20^{\prime \prime} \mathrm{E}-37^{\circ} 15^{\prime} 48^{\prime \prime} \mathrm{E}$ long. The elevation of the district ranges from $700 \mathrm{~m}$ to $2600 \mathrm{~m}$ above sea level (masl). District is composed of three agro-ecological zones namely high land, midland, and low land.

The topography of Loma Bosa district varies from undulating landscape to an extended, steep slope and mountains. The district is a source of many perennial and seasonal rivers, which flow to Omo river, the largest river in southern Ethiopia. Those rivers are Karata, Koma, Bokoli, Ugumono, Tone, Wuni, Maula, Koranto and Manta. Currently, Omo river the main source of electric power to the Ethiopia. Different hydroelectric dams such as Gibe I, II, III and Koyisha (Gibe IV-under construction) are station on Omo river.

The soil characteristics of the district varies with its agro-ecological zones and landscapes of the catchments area. In high land agro-ecological zone, the soil is the deeper than other two agro ecological zones; but fertility states is less because of steeper slope of the farmland and high rainfall. As result the farmer in high land agro-ecology are using commercial fertilizer, farmyard manure and compost for crop production. In the low land, the depth of the soil is very less and stone is frequent in farmland, as result stone bund constructed on farming land and closed area in communal land. However, in all three agro-ecological zones of the district, deforestation, soil erosion and land degradation are the major problem due to topographic future and misuse of forest resources.

Zima Waruma (Fig. 2), the study site, is located in Loma Bosa district of the Dawuro zone. The altitude of Zima Waruma lies 720 to $1800 \mathrm{masl}$, and has an annual rainfall of $1000-1300 \mathrm{~mm}$. The climatic condition of the area is lowland agro climatic zone; the amount of rainfall distribution through the year is erratic. The study area receives less rain than the other Kebeles in the Loma Bosa distirct. The temperature range in the area is $15.1-27.5^{\circ} \mathrm{C}$ with the higher temperature in the lower part of the watershed or Omo river. The soil of the study site is classified under Orthic Acrisols. The population of Zima Waruma is about 3,724, of which 1879 male and 1845 is female. Mixed agriculture (crop production and livestock rearing) is the main economic activity in the study site. The major crops are grown in the areas include, Zea mays L., Sorghum bicolor, Eragrostis tef, Phaseolus vulgaris, Ipomoea batatas and Manihot esculenta are widely cultivated (Wolka et al., 2013).

\subsection{Sampling and data collection techniques}

Since this is the first investigation after establishment of the closed area, it is challenge to explain the full process of the veqetation dvnamics in studv site. However, changes after the establishment of closed area Loading [MathJax]/jax/output/CommonHTML/jax.js 
were described using some important parameters such as woody species composition (relative contribution of individual species; density and cover) and diversity measurements (e.g., richness and evenness) in the study site (Seid et al., 2020) compared with the open woodland and adjacent open lands. The assumption in this study is that the closed area and open areas had similar conditions before establishment of the closed area.

\subsubsection{Sampling techniques}

To obtain overviews of the closed area activities and woody species regeneration, the reconnaissance survey was made in 2018 before the actual fieldwork in the study area. Contacts were made and consent had reached with the Dawuro zone Agriculture and Natural Resource and Department of environment, forest and climate change at Loma Bosa district before starting actual fieldwork. Accordingly, they assigned the technical experts who have experience on natural resource data collection to assist and facilitate the data collection process. Specific training and orientation on collecting the data and on filling the questioners were given for all experts involved in the data collection. Moreover, a brief introduction about the purpose of the study was given for the kebele (village) administrations and other stakeholders. After introduction, kebele leaders and development agents were identified the specific closed, open woodland, and open degraded land area for vegetation survey on woody species regeneration assessment.

\subsubsection{Data collection method and Sample size}

Systematic data collection approach was used to determine the composition and density of woody plants in the closed, open woodland and open degraded land areas in the site. Parallel line transects, which have $200 \mathrm{~m}$ apart from each other, were laid crossing the study sites from west to east direction. Along each transect, sample plot quadrats measuring $20 \mathrm{~m}$ by $20 \mathrm{~m}\left(400 \mathrm{~m}^{2}\right)$ were laid down at $50 \mathrm{~m}$ intervals. Accordingly, 30 quadrants were laid in study sites. Of 30 quadrants, 12 were from the each of the closed and open woodland areas, while the rest 6 quadrants were laid in open degraded land area near the closed site. In each of these quadrates, the identity and number of all individuals of woody species were determined and recorded.

\section{- 2.3.Data and analysis}

\subsubsection{Woody vegetations data anlsysis}

The density of each woody plant per hectare was derived from the total number of individuals recorded in the total quadrants, at the closed land, open woodland, and open degraded land areas of study site. The species diversities in all land use types (closed, open woodland, and open degraded land areas) of the study sites were calculated using Simpson's Diversity Index and Shannon-Wiener Index.

The Simpson's Diversity Index was developed by Simpson (1949) and given as!

$$
\mathrm{D}=?\left(\frac{n i(n i-1)}{N(N-1)}\right)(1)
$$


Where D is Simpson's diversity index, which ranges the value between zero and one. The zero value represents infinite diversity and one represents no diversity. That is, the bigger the value of $D$, the lower the diversity of tree species. $n_{i}$ is number of individual woody species in the closed land, open woodland, or open degraded land areas; and $\mathrm{N}$ is total number of woody species in the closed land, open woodland or open degraded land areas (total number of woody species in the sample).

The Shannon-Weiner index (Barnes et al. 1998) assumes that all species are represented in a sample and that the sample was obtained randomly. The index obtained from the following equation!

$$
\mathrm{H}^{\prime}=-?_{i=1}^{R} \ln (P i)=\ln \left(\frac{1}{?_{i=1}^{R} P i^{P i}}\right) 2
$$

Where pi is is the proportion of individuals that belong to species $i$; $R$ is the number of species in the sample, and $\mathrm{In}$ is the natural logarithm. The term in the parenthesis equal to the true diversity (i.e., $D$ ) and $H^{\prime}=\ln (D)$. $A$ limitation for Shannon-Weiner index is that its value usually biased toward measuring species richness in a sample.

Evenness index $(\mathrm{J})$ or equitability of species was calculated using the Shannon Evenness index equation as $\square$

$$
\mathrm{J}=\frac{H^{\prime}}{H^{\prime} \operatorname{Max}}=\frac{H^{\prime}}{\ln ?(R)} \frac{-?_{i=1}^{R} \ln ?(\mathrm{pi})^{\prime}}{\ln R} 3
$$

Where $H^{\prime}$ Max is equal to $\ln (\mathrm{R})$; $\mathrm{H}^{\prime}$ represents Shannon diversity index; InR represents the natural logarithm of the total number of species in each community, and $\mathrm{R}$ represents the number of species in each community (Shannon and Weiner, 1949). The higher the values of Shannon evenness (J), the more even the species are by their distribution. Likewise, the higher the value of Shannon diversity index $\left(\mathrm{H}^{\prime}\right)$, the more diverse the community are. If the community has one species, the index will be close to zero. If all species in the data set are equally common, all $p$ i values will be equal to $1 / R$ and the Shannon-Weiner index equals $\ln (R)$. The collected data from each closed area, based on the parameters indicated above, ware compared to its adjacent open land to evaluate the effect of closed area on species richness and diversity.

The similarity between the closed area and open areas in their woody species vegetation was analyzed using Sørenson's Similarity Coefficient (SSC) (Krebs, 1999; Tamrat, 1993).

$$
\mathrm{SSC}=\frac{2 a}{2 a}+b+c=4
$$

Where a represents number of plant species common to both habitats (i.e., closed and open areas); $b$ represents number of species in the first habitat but absent in the second; and c represents number of species preset in the second habitat but absent in the first.

\section{Results And Discussion}




\subsection{Woody species regeneration comparisions \\ 3.1.1 Woody species composition among habitats}

Tables 1, 2, and 3 presents' individual and woody species counted and recorded from closed land, open woodland, and degraded land areas of the study site, respectively. A total of 1,068 individuals and 23 woody species were counted and recorded from closed land area, while 788 individuals and 22 woody species were recorded from the open woodland area. About 67 individuals and 8 woody species were recorded from open degraded land area. In general, 1,923 individuals and 26 woody species were recorded for purposes of this study. Of the total recorded woody species, 19 (73.1\%) were common to closed land and open woodland areas, while $8(30.77 \%)$ were common to both habitats (closed and open land areas of the total sample). The results from the vegetation composition analysis indicated that closed land areas have the richest woody vegetation composition than other habitats in the study sites. Four woody species namely Dedonaea viscosa (18.5\%), Sobuwa in local name (18.3\%), Conbretum collinum (18\%), and Dichrostrachys cinocera (16.7\%) were the most dominant composition constituting $71.5 \%$ of the total woody vegetation species in the closed areas. On the other hand, Dichrostrachys cinocera (26.9\%), Dedonaea viscosa (14.2\%), and Sobuwa in local name (10.4\%) were the most dominant composition woody species consisting $61.9 \%$ of the total woody species in the open woodland. The open degraded land is dominated by 3 woody species namely Prosopis juliflora (26.9\%), Grewia bicolor (17.9\%), and Dichrostrachys cinocera (14.9\%). Together, they consisted $59.7 \%$ of the total woody species in open degraded land. 
Table 1

Species composition in the closed land area.

\begin{tabular}{|c|c|c|c|c|c|c|c|c|}
\hline \multirow[t]{2}{*}{ No. } & \multirow{2}{*}{$\begin{array}{l}\text { Scientific } \\
\text { name of } \\
\text { species }\end{array}$} & \multirow{2}{*}{$\begin{array}{l}\text { Local name } \\
\text { of species } \\
\text { Dawuregna }\end{array}$} & \multicolumn{5}{|c|}{$\begin{array}{l}\text { Number of species counted in closed area in life } \\
\text { form* }\end{array}$} & \multirow{2}{*}{$\begin{array}{l}\text { Species } \\
\text { composition } \\
\text { closed area } \\
\text { (\%) }\end{array}$} \\
\hline & & & Trees & Shrubs & Saplings & Seedlings & Total & \\
\hline 1 & $\begin{array}{l}\text { Dichrostrachys } \\
\text { cinocera }\end{array}$ & Burguduwa & 44 & 8 & 15 & 111 & 178 & 16.7 \\
\hline 2 & Aloe vera & \multicolumn{4}{|l|}{ Godareuta } & 3 & 3 & 0.3 \\
\hline 3 & $\begin{array}{l}\text { Albizia } \\
\text { gradibracteate }\end{array}$ & Karchiituwa & \multicolumn{2}{|l|}{40} & 3 & 15 & 58 & 5.4 \\
\hline 4 & $\begin{array}{l}\text { Combretum } \\
\text { mole }\end{array}$ & Anbiya & \multicolumn{2}{|l|}{50} & 6 & 24 & 80 & 7.5 \\
\hline 5 & $\begin{array}{l}\text { Dedonaea } \\
\text { viscosa }\end{array}$ & \multicolumn{2}{|l|}{ Sanakara } & 175 & 23 & & 198 & 18.5 \\
\hline 6 & $\begin{array}{l}\text { Flacourtia } \\
\text { indica }\end{array}$ & Miliazuwa & \multicolumn{3}{|l|}{2} & & 2 & 0.2 \\
\hline 7 & Grewia bicolor & Ugugiya & 2 & 3 & 3 & 4 & 12 & 1.1 \\
\hline 8 & $\begin{array}{l}\text { Prosopis } \\
\text { juliflora }\end{array}$ & Gargaruwa & 7 & 5 & 15 & 2 & 29 & 2.7 \\
\hline 9 & $\begin{array}{l}\text { Strychos } \\
\text { innocua }\end{array}$ & Genbela & \multicolumn{3}{|l|}{5} & & 5 & 0.5 \\
\hline 10 & Vitex doniane & \multicolumn{4}{|l|}{ Shina } & 2 & 2 & 0.2 \\
\hline 11 & & \multicolumn{2}{|l|}{ Hagiluwa } & \multicolumn{2}{|l|}{12} & 2 & 14 & 1.3 \\
\hline 12 & $\begin{array}{l}\text { Conbretum } \\
\text { collinum }\end{array}$ & Digsuwa & 131 & 5 & 13 & 43 & 192 & 18.0 \\
\hline 13 & & Sobuwa & 146 & 14 & 17 & 18 & 195 & 18.3 \\
\hline 14 & & Teema & & & & 3 & 3 & 0.3 \\
\hline 15 & $\begin{array}{l}\text { Terminalia } \\
\text { brownie }\end{array}$ & Galaluwa & 3 & 3 & 2 & 2 & 10 & 0.9 \\
\hline 16 & & Tsawayia & 2 & 6 & 8 & 7 & 23 & 2.2 \\
\hline 17 & & Saga & 2 & & 4 & 4 & 10 & 0.9 \\
\hline 18 & & Gelceca & 2 & 3 & 15 & 7 & 27 & 2.5 \\
\hline 19 & & Dobiya & 2 & & & 4 & 6 & 0.6 \\
\hline 20 & & Atiya & & & & 2 & 2 & 0.2 \\
\hline \multicolumn{9}{|c|}{$\begin{array}{l}\text { *Seedlings indicate less than } 0.5 \mathrm{~m} \text { height only of which their numbers were counted. Seedling is less than } \\
2.5 \mathrm{~cm} \text { at DBH and below } 1.5 \mathrm{~m} \text { in height, saplings at DBH } 2.5 \mathrm{~cm} \text { and height between } 1.5 \mathrm{~cm} \text { to } 2 \mathrm{~m} \\
\text { above around, shrubs all multi-stem woody plants below stump height with DBH more than } 2.5 \mathrm{~cm} \text { and } \\
\text { Loading [MathJax]/jax/output/CommonHTML/jax.js above } 2.5 \mathrm{~cm} \text { and height more than } 2 \mathrm{~m} \text {. }\end{array}$} \\
\hline
\end{tabular}




\begin{tabular}{|c|c|c|c|c|c|c|c|c|}
\hline \multirow[t]{2}{*}{ No. } & \multirow{2}{*}{$\begin{array}{l}\text { Scientific } \\
\text { name of } \\
\text { species }\end{array}$} & \multirow{2}{*}{$\begin{array}{l}\text { Local name } \\
\text { of species } \\
\text { Dawuregna }\end{array}$} & \multicolumn{5}{|c|}{$\begin{array}{l}\text { Number of species counted in closed area in life } \\
\text { form }^{*}\end{array}$} & \multirow{2}{*}{$\begin{array}{l}\text { Species } \\
\text { composition } \\
\text { closed area } \\
(\%)\end{array}$} \\
\hline & & & Trees & Shrubs & Saplings & Seedlings & Total & \\
\hline 21 & & Kasiyo & & & & 3 & 3 & 0.3 \\
\hline 22 & & Futawuwa & & 4 & 4 & 5 & 13 & 1.2 \\
\hline \multirow[t]{2}{*}{23} & $\begin{array}{l}\text { Ficus } \\
\text { sycomorus }\end{array}$ & Eta & 3 & & & & 3 & 0.3 \\
\hline & Total & & 441 & 238 & 128 & 261 & 1068 & 100.0 \\
\hline \multicolumn{9}{|c|}{$\begin{array}{l}\text { * Seedlings indicate less than } 0.5 \mathrm{~m} \text { height only of which their numbers were counted. Seedling is less than } \\
2.5 \mathrm{~cm} \text { at } D B H \text { and below } 1.5 \mathrm{~m} \text { in height, saplings at } D B H 2.5 \mathrm{~cm} \text { and height between } 1.5 \mathrm{~cm} \text { to } 2 \mathrm{~m} \\
\text { above ground, shrubs all multi-stem woody plants below stump height with DBH more than } 2.5 \mathrm{~cm} \text { and } \\
\text { height more than } 0.5 \mathrm{~m} \text {, and trees at DBH above } 2.5 \mathrm{~cm} \text { and height more than } 2 \mathrm{~m} \text {. }\end{array}$} \\
\hline
\end{tabular}


Table 2

Species composition in the open woody land area.

\begin{tabular}{|c|c|c|c|c|c|c|c|c|}
\hline \multirow[t]{2}{*}{ No. } & \multirow{2}{*}{$\begin{array}{l}\text { Scientific } \\
\text { name of } \\
\text { species }\end{array}$} & \multirow{2}{*}{$\begin{array}{l}\text { Local name } \\
\text { of species } \\
\text { Dawuregna }\end{array}$} & \multicolumn{5}{|c|}{$\begin{array}{l}\text { Number of species counted in open wood land } \\
\text { area in life form }\end{array}$} & \multirow{2}{*}{$\begin{array}{l}\text { Species } \\
\text { composition } \\
\text { open } \\
\text { woodland } \\
\text { (\%) }\end{array}$} \\
\hline & & & Trees & Shrubs & Saplings & Seedlings & Total & \\
\hline 1 & $\begin{array}{l}\text { Dichrostrachys } \\
\text { cinocera }\end{array}$ & Burguduwa & 26 & & 2 & 184 & 212 & 26.9 \\
\hline 2 & Aloe vera & Godareuta & & & & 2 & 2 & 0.3 \\
\hline 3 & $\begin{array}{l}\text { Albizia } \\
\text { gradibracteate }\end{array}$ & Karchiituwa & 26 & & 8 & 12 & 46 & 5.8 \\
\hline 4 & $\begin{array}{l}\text { Conbretum } \\
\text { mole }\end{array}$ & Anbiya & 20 & & & 10 & 30 & 3.8 \\
\hline 5 & $\begin{array}{l}\text { Dedonae } \\
\text { acicosa }\end{array}$ & Sanakara & & 112 & & & 112 & 14.2 \\
\hline 6 & $\begin{array}{l}\text { Flacourtia } \\
\text { indica }\end{array}$ & Miliazuwa & 2 & & & & 2 & 0.3 \\
\hline 7 & Grewia bicolor & Ugugiya & 2 & & & & 2 & 0.3 \\
\hline 8 & $\begin{array}{l}\text { Pilostigma } \\
\text { thonningii }\end{array}$ & Kanakala & & & & 4 & 4 & 0.5 \\
\hline 9 & $\begin{array}{l}\text { Prosopis } \\
\text { juliflora }\end{array}$ & Gargaruwa & & 66 & & 16 & 82 & 10.4 \\
\hline 10 & $\begin{array}{l}\text { Strychos } \\
\text { innocua }\end{array}$ & Genbela & & & & 6 & 6 & 0.8 \\
\hline 11 & & Hagiluwa & 4 & & 10 & 4 & 18 & 2.3 \\
\hline 12 & $\begin{array}{l}\text { Conbretum } \\
\text { collinum }\end{array}$ & Digsuwa & 42 & 2 & 6 & 20 & 70 & 8.9 \\
\hline 13 & & Sobuwa & 33 & 4 & 6 & 39 & 82 & 10.4 \\
\hline 14 & $\begin{array}{l}\text { Balantiece } \\
\text { aegyptiaca }\end{array}$ & Badanuwa & 2 & & & 8 & 10 & 1.3 \\
\hline 15 & & Teema & 2 & & 4 & 4 & 10 & 1.3 \\
\hline 16 & & Sisleta & & 2 & & & 2 & 0.3 \\
\hline 17 & $\begin{array}{l}\text { Terminalia } \\
\text { brownie }\end{array}$ & Galaluwa & 14 & & 6 & 8 & 28 & 3.6 \\
\hline 18 & & Tsawayia & & & 4 & & 4 & 0.5 \\
\hline 19 & & Gelceca & 4 & & 4 & 18 & 26 & 3.3 \\
\hline 20 & & Dobiya & 4 & & & 2 & 6 & 0.8 \\
\hline
\end{tabular}




\begin{tabular}{|c|c|c|c|c|c|c|c|c|}
\hline \multirow[t]{2}{*}{ No. } & \multirow{2}{*}{$\begin{array}{l}\text { Scientific } \\
\text { name of } \\
\text { species }\end{array}$} & \multirow{2}{*}{$\begin{array}{l}\text { Local name } \\
\text { of species } \\
\text { Dawuregna }\end{array}$} & \multicolumn{5}{|c|}{$\begin{array}{l}\text { Number of species counted in open wood land } \\
\text { area in life form }\end{array}$} & \multirow{2}{*}{$\begin{array}{l}\text { Species } \\
\text { composition } \\
\text { open } \\
\text { woodland } \\
\text { (\%) }\end{array}$} \\
\hline & & & Trees & Shrubs & Saplings & Seedlings & Total & \\
\hline 21 & & Atiya & & & 2 & 6 & 8 & 1.0 \\
\hline 22 & & Futawuwa & & & 4 & 22 & 26 & 3.3 \\
\hline & Total & & 181 & 186 & 56 & 365 & 788 & 100 \\
\hline
\end{tabular}

Table 3

Species composition in the open degraded land area.

\begin{tabular}{|c|c|c|c|c|c|c|c|c|}
\hline \multirow[t]{2}{*}{ No. } & \multirow{2}{*}{$\begin{array}{l}\text { Scientific } \\
\text { name of } \\
\text { species }\end{array}$} & \multirow[t]{2}{*}{$\begin{array}{l}\text { Local name } \\
\text { of species }\end{array}$} & \multicolumn{5}{|c|}{$\begin{array}{l}\text { Number of species counted in open bare land in } \\
\text { life form. }\end{array}$} & \multirow{2}{*}{$\begin{array}{l}\text { Species } \\
\text { composition } \\
\text { open } \\
\text { degraded } \\
\text { land (\%) }\end{array}$} \\
\hline & & & Trees & Shrubs & Saplings & Seedlings & Total & \\
\hline 1 & $\begin{array}{l}\text { Dichrostrachys } \\
\text { cinocera }\end{array}$ & Burguduwa & 1 & 5 & 2 & 2 & 10 & 14.9 \\
\hline 2 & $\begin{array}{l}\text { Albizia } \\
\text { gradibracteate }\end{array}$ & Karchiituwa & 2 & & 1 & 1 & 4 & 6.0 \\
\hline 3 & $\begin{array}{l}\text { Conbretum } \\
\text { mole }\end{array}$ & Anbiya & 5 & & 1 & & 6 & 9.0 \\
\hline 4 & Grewia bicolor & Ugugiya & 2 & 3 & 3 & 4 & 12 & 17.9 \\
\hline 5 & $\begin{array}{l}\text { Prosopis } \\
\text { juliflora }\end{array}$ & Gargaruwa & 7 & 5 & 3 & 3 & 18 & 26.9 \\
\hline 6 & $\begin{array}{l}\text { Strychos } \\
\text { innocua }\end{array}$ & Genbela & 5 & & & & 5 & 7.5 \\
\hline 7 & $\begin{array}{l}\text { Conbretum } \\
\text { collinum }\end{array}$ & Digsuwa & 2 & 2 & & & 4 & 6.0 \\
\hline 8 & & Sobuwa & 2 & 5 & & 1 & 8 & 11.9 \\
\hline & Total & & 26 & 20 & 10 & 11 & 67 & 100 \\
\hline
\end{tabular}

The comparison made among the closed land, open woodland, and open degraded land areas of the study sites. The present study clearly demonstrated the importance of the closed area for the regeneration of woody species. The results showed that the composition of woody species regeneration in closed land area were higher than that of the open woodlands and open degraded land areas. This is due to the contribution of restriction from human and livestock interference that assisted the regeneration and succession of overall vegetation and woody species in the study site. The lower results of vegetation composition in open wood Loading [MathJax]/jax/output/CommonHTML/jax.js ] to the consequence of human and livestock interferences such 
as illegal cutting of trees, free or over grazing, and absence of effective keeping system. This result is consistent with the studies that concluded as humans modify the floristic composition and structure of forests during the process of utilization for their immediate purpose of best goods and services (Wiersum, 1997), but activities such as establishment of the closed area are among other factors that assist in improving the overall ecological conditions of degraded land areas (Mengistu et al., 2005) and allowed regeneration of woody species.

\subsubsection{Species richness, diversity and evenness}

A combination of the number of species and their relative abundance defines the species diversity in general and woody species in particular. The value of woody species diversity depends on the level of species richness and evenness. This study has shown species richness in the closed area is the higher than among other corresponding habitats.

The diversity value was tested in both Simpson's and Shannon Weiner Diversity index (Table 4). The results indicated that closed land areas have the highest Simpson's Diversity Index than open woodland and degraded land areas. Simpson's Diversity Index values were 7.24, 6.01 and 3.4 for closed land area, open woodland, and open degraded land areas, respectively. Since these figures were obtained by using the inverse, the diversity index value starts with 1 as the lowest possible figure. That is it implies the higher the value of the inverse index, the greater the diversity of the woody species in the sample. If we use the compliment to Simpson's D, the diversity index value of closed area, open woodland, and open degraded land areas will be $0.138,0.167$, and 0.294 , respectively. In this case, the index has values ranging from 0 to 1 . That is higher the value, lower the diversity of the woody species in a sample. Thus, the lower value of $(D=0.138)$ for closed area indicates the higher diversity of the woody species in a sample. In both cases, the Simpson Diversity index values of closed area indicate that if two individuals randomly selected from a sample the probability that they belongs to different woody species would be higher compared to open wood and open degraded lands. However, the results from Shannon Weiner Diversity index indicated that closed area have slightly lower value than open woodland area. Shannon Weiner diversity index of the wood species were 2.26, 2.38, and 1.56 for closed area, open woodland area and open degraded land area, respectively. Shannon index values indicate that relatively more unequal abundance of woody species in the closed area than open woodland area. That is there are small number of woody species in closed areas than open woodland areas. This result is also confirmed by evenness value.

The results of evenness value $(\mathrm{J})$ of woody species were found to be $0.721,0.770$, and 0.751 for the closed area, open woodland and open degraded land areas, respectively. Low evenness of woody species in closed area reveals that the areas are dominated by a few woody species. This is because, of an illegal cutting of naturally regenerated seedling with grass, planting of a few tree species by the development program, and protection of existing shrubs and trees from illegal cutting which resulted dominance of a few woody species in the closed area. Hence, dominance is inversely related to evenness, the closed areas are considered to be dominated by few species but with higher species richness than other habitats (see Table 4). The result is consistent with the studies by (Giday, 2002 and Mengistu et al., 2005) that showed closed area enhanced species richness, diversity and vegetation regeneration. This higher proportion of woody vegetation in the 
closed area suggests the existence of an active regeneration and succession of woody vegetation's. This resulted due to restriction of humans, animal interference and effective keeping system.

Table 4

Woody species diversity, richness, evenness density per ha in closed area, open wood land area and open degraded land area

\begin{tabular}{|c|c|c|c|c|c|c|c|}
\hline $\begin{array}{l}\text { Habitat } \\
\text { types }\end{array}$ & $\begin{array}{l}\text { Sample } \\
(\mathrm{N}) \\
400 \mathrm{~m}^{2} \\
\text { quadrants }\end{array}$ & $\begin{array}{l}\text { Simpson's } \\
\text { Diversity } \\
\text { Index }\end{array}$ & $\begin{array}{l}\text { Shannon-Weiner } \\
\text { Diversity } \\
\text { Index }\left(H^{\prime}\right)\end{array}$ & $\begin{array}{l}\mathrm{H}^{\prime} \\
\max \\
\text { or } \\
\mathrm{LN}(\mathrm{s})\end{array}$ & $\begin{array}{l}\text { Species } \\
\text { Richness } \\
\text { (S) }\end{array}$ & $\begin{array}{l}\text { Evenness } \\
\text { (J) }\end{array}$ & $\begin{array}{l}\text { Woody } \\
\text { species } \\
\text { density } \\
\text { per ha }\end{array}$ \\
\hline $\begin{array}{l}\text { Closed } \\
\text { area }\end{array}$ & 12 & 7.24 & 2.26 & 3.135 & 23 & 0.721 & 2225 \\
\hline $\begin{array}{l}\text { Open } \\
\text { woodland }\end{array}$ & 12 & 6.01 & 2.38 & 3.091 & 22 & 0.770 & 1642 \\
\hline $\begin{array}{l}\text { Open } \\
\text { degraded } \\
\text { land }\end{array}$ & 6 & 3.40 & 1.56 & 2.079 & 8 & 0.751 & 279 \\
\hline
\end{tabular}

The result showed that the species richness, diversity and density of woody species were significantly higher in the closed area than open degraded land suggesting closed area enhanced woody species regeneration in relatively short periods by avoiding or minimizing human and livestock interference in the degraded areas. Similar results were reported by Birhane (2002), Giday (2002) and Mengistu et al. (2005) from northern Ethiopia.

\subsubsection{Woody vegetation similarity}

Sorenson's Similarity Coefficient (SSC) was used to determine the similarity among woody species with in habitats. The number of woody species common to both closed area and open wood land were 19 woody species. The number of species present in the closed area habitat but absent in the open wood land were 4 woody species. Whereas number of species present in the open wood land habitat but absent in the closed area were 3 woody species, those woody species identified in open degraded land area were 8 woody species. The number of woody species found in closed area but absent in degraded land area were 15 woody species. The number of woody species present in the open woodland area but absent in open degraded land were 14 wood species. The Sorensen's similarity coefficients were 0.844 (84.4\%), 0.516 (51.6\%) and 0.533 (53.3\%) between closed area and open woodland, between closed area and open degraded land and between open woodland area and open degraded land woody vegetation similarity, respectively (Table 5). 
Table 5

Similarity coefficient among habitat types.

\begin{tabular}{|llll|}
\hline Habitats & Closed area & Open woodland & Open degraded land \\
\hline Closed area & 1 & & \\
\hline Open woodland & 0.844 & 1 & 1 \\
\hline Open degraded land & 0.516 & 0.533 & \\
\hline Source: Field survey results & & \\
\hline
\end{tabular}

There is similarity of woody species regeneration across the closed area and woodland of study sites. This similarity may be due to altitudinal range, geographic location, climatic conditions and the woody vegetation composition. There is variation of woody species composition between closed area and open degraded and. This in turn may be due to a closed area developments, which increases the species regeneration by protecting from human and livestock interferences. The composition of woody species similarity across the sites is also not even. There is variation among closed, open woodland and open degraded lands, because the closed area is supported by protection that made the rich in species composition.

\subsubsection{Density of woody species in life form}

The density of woody species defined in this study as number of stems per hectare of all woody species in life form. The density of woody vegetation was $2,225 \mathrm{ha}^{-1}, 1642 \mathrm{ha}^{-1}$, and $297 \mathrm{ha}^{-1}$ for closed area, open woodland and open degraded land area, respectively. The presence of each vegetation categories like seedling, sapling, tree and shrub in both sites indicated the regeneration potential of the sites. The proportion of trees, shrubs, saplings and seedlings were $42.22 \%, 18.82 \%, 14.98 \%$ and $23.97 \%$, respectively, in the closed area. On the other hand, in the corresponding open woodland area the trees, shrubs, saplings, and seedlings composed were found to be $22.97 \%, 23.60 \%, 7.11 \%$ and $46.32 \%$, respectively. In the open degraded land the compositions of trees, shrubs, saplings, and seedlings were $36.4 \%, 28 \%, 14.1 \%$ and $15.5 \%$, respectively (Table 6). Total density of woody in closed area significantly exceeds the density of their relatives in open woodland and degraded land. Less seedling density were counted in closed area may be because much seedlings were cut down due to grass cutting system. The density per ha of seedling in open wood land was higher than that of the closed area, but its growth potential to the next generation was less than closed area due to sever disturbance regime ( $87 \%$ the seedling not survived to sapling). Therefore, closed area resulted in the best growth potential to the next generation and highest percentage of tree in study site. This indicating the effect of closed area management and effective protection of land promoted woody vegetation density and regeneration in closed area. This result is in harmony with a study by Birhane (2002) who concluded that closed area increased woody species density in Ethiopia. 
Table 6

Density of woody species composition by life form and total density between habitats per hectare.

\begin{tabular}{|c|c|c|c|c|c|}
\hline Habitat & ${ }_{1}^{\text {Seedlings ha }}{ }^{-}$ & Saplings ha-1 & Shrubs ha-1 & Trees ha-1 & $\begin{array}{l}\text { Total } \\
\text { density ha } \\
1\end{array}$ \\
\hline Closed area & $543.8(24.4 \%)$ & $235.4(14.98 \%)$ & $516.7(18.82 \%)$ & $939.6(42.22 \%)$ & 2225 \\
\hline Open woodland & $760.4(46.32 \%)$ & $116.7(7.11 \%)$ & $387.5(23.60 \%)$ & $377.1(22.97 \%)$ & 1642 \\
\hline $\begin{array}{l}\text { Open degraded } \\
\text { land }\end{array}$ & $46(15.5 \%)$ & $42(14.1 \%)$ & $83(28 \%)$ & $108(36.4 \%)$ & 297 \\
\hline
\end{tabular}

Source: Field survey results

\subsubsection{Regeneration of woody species between habitats and within habitats}

Density and composition of seedlings and saplings would indicate the status of woody species regeneration in the study area. Based on the regeneration status of 26 different woody species composition in closed area, open woodland, and open degraded land in the study site, the seedling occurred were $544 \mathrm{ha}^{-1}, 760 \mathrm{ha}^{-1}$ and $46 \mathrm{ha}^{-1}$, respectively. Saplings occurred were $267 \mathrm{ha}^{-1}, 117 \mathrm{ha}^{-1}$ and $33 \mathrm{ha}^{-1}$ in the closed area, open woodland and open degraded land, respectively. Trees and shrubs were 1,415 ha-, $765 \mathrm{ha}^{-1}$ and $191 \mathrm{ha}^{-1}$ in the closed area, open woodland and open degraded land, respectively. Closed area showed highest density of trees/shrubs and saplings. Open woodland showed the highest seedling but less survival of sapling. The open degraded land lest density of seedling and sapling. In open area the highest disturbance regime affected regeneration. Thus, conservation strategy is needed to save ruminant's wood vegetation of ConbretumTerminalia woodland (Table 6 and Fig. 3).

Based on the regeneration status of 23 different woody species composition within closed area the seedling, sapling and trees or shrubs occurred species has 12 (52.2\%) out of 23 woody species (Fig. 4). Taking seedlings into consideration 4 woody species for examples Dedonaea viscosa, Flacourtia indica, Strychos innocua, and Ficus sycomorus not found by seedling stage in closed area. Taking sapling in the consideration 10 woody species for examples Aloe vera, Flacourtia indica, Strychos innocua, Vitex doniane, Hagiluwa (in local name), Teema (local name), Dobiya (local name), Atiya (local name), Kasiyo (local name) and Ficus sycomorus not represented by sapling stage in closed area. Taking trees/shrubs in to consideration Aloe vera, Vitex doniane, Teema, Atiya (local name) and Kasiyo woody species not represented by trees/shrubs stage in closed area (see, Table 1). Sobowa and Conbretum collinum are the two most dominating trees and Dichrostrachys cinocera the most dominating woody species at seedling stage in closed area (Fig. 4).

Based on the regeneration status of 22 different woody species composition in open woodland of study site the seedling, sapling and trees or shrubs occurred species is 8(36.4\%) out of 22 woody species (Fig. 5). Taking seedlings into consideration 5 woody species Dedonaea viscosa, Flacourtia indica, Grewia bicolor, Sisleta (local name) and Ficus sycomorus out of 22 species not found by seedling stage in open woodland. Taking sapling in the consideration 11 (50\%) woody species for examples Aloe vera, Conbretum molle, Dedonaea Loading [MathJax]/jax/output/CommonHTML/jax.js lostigma thonningii, Prosopis juliflora, Strychos innocua, 
Balantiece aegyptiaca, Sisleta (local name) and Dobiya (local name) are not represented by sapling stage in open wood land. Aloe vera, Pilostigma thonningii, Strychos innocua, Tsawayia (local name), Atiya (local name) and Futawuwa (local name) are not represented by trees/shrubs stage in open woodland of study site. Dichrostrachys cinocera is the most dominating seedling woody species in open woodland (Table 2 and Fig. 5).

The regeneration status of 8 different woody species composition in open degraded land of Zima Waruma study site the seedling, sapling and trees or shrubs occurred species is $4(50 \%)$ out of 8 woody species (Fig. 6 ) Albizia granibracteate, Dichrostrachys cinocera, Grewia bicolor and Prosopis juliflora are example of woody species found at both stages. Conbretum molle, Strychos innocua and Conbretum collinum are not found in seedling stage at degraded land. Taking sapling in the consideration 3 woody species such as Strychos innocua, Conbretum molle and Sobowa (local name) are not represented as sapling stage in open degraded area. In the open degraded land all of 8 woody species represented as trees/shrubs stage in the study site. Shrubs are affected by live stocks and old aged scattered few trees remained for the shading. This indicates the land in the past was wood land and gradually it changed to present level of vegetation through disturbance and which negatively affected the regeneration status of the degraded land area. Therefore, conservation strategy such as closed area and other natural resources development are needed for future regeneration.

\subsubsection{Diameter at Breast Height (DBH) and Height of woody species}

The DBH classes were divided into seven classes from DBH 0.1-5 cm to DBH 30.1-35 cm classes in both habitats. The DBH class distribution of closed area reveled up to six classes. The DBH distribution analysis of woody species result in this habitat has shown that the DBH class constituted the majority of woody species densities per ha (compared to the other two) habitats. The density of woody species in DBH $0.1-5 \mathrm{~cm}$ class has shown $925 \mathrm{ha}^{-1}, 982 \mathrm{ha}^{-1}$ and $183 \mathrm{ha}^{-1}$ in closed area, open woodland and open degraded land, respectively. Similarly, the density of woody species at DBH class $5.1-10 \mathrm{~cm}$ were $597 \mathrm{ha}^{-1}, 247 \mathrm{ha}^{-1}$ and $29 \mathrm{ha}^{-1}$ in closed area, open woodland and open degraded land, respectively. On the other hand, the density of woody species at DBH class 10.1-15 cm were $305 \mathrm{ha}^{-1}, 174 \mathrm{ha}^{-1}$ and $22 \mathrm{ha}^{-1}$ in closed area, open woodland and open degraded land, respectively. As far as the density of woody species at DBH class 15.1$20 \mathrm{~cm}$ is concerned, it was registered as $206 \mathrm{ha}^{-1}, 123 \mathrm{ha}^{-1}$ and $33 \mathrm{ha}^{-1}$ in closed area, open woodland and open degraded land, respectively. Whereas the density of woody species at DBH class $20.1-25 \mathrm{~cm}$ was $125 \mathrm{ha}^{-1}$ and $72 \mathrm{ha}^{-1}$ in closed area and open woodland, respectively; at DBH class $25.1-30 \mathrm{~cm}$ were $67 \mathrm{ha}^{-}$

$1,11 \mathrm{ha}^{-1}$ and $4 \mathrm{ha}^{-1}$ in closed area, open woodland and open degraded land, respectively. The density of woody species at DBH class $30.1-35 \mathrm{~cm}$ was $2 \mathrm{ha}^{-1}, 11 \mathrm{ha}^{-1}$ and $8 \mathrm{ha}^{-1}$ in open woodland and open degraded land, respectively.

The density of woody species in closed area was the highest from other habitats and all DBH classes except the first and last class (Fig. 7). This indicates that closed area activity enhanced woody species regeneration. Closed area promoted species density and protection from interference improved diameter size. Other study Loading [MathJax]/jax/output/CommonHTML/jax.js nsures the probability of plant growth to high diameter size which 
will enhance the probability of seed-bearing plants for seed dispersal and germination to seedlings (Teketay, 1997), which enhance future regeneration. Accordingly, the woody vegetation frequency distribution in closed area and open woodland showed inverted $\mathrm{J}$ shape pattern of distribution indicating high degree of woody vegetation heterogeneity (Shibru \& Balcha, 2004). Open woodland a sharp decline of first DBH class to the second class affected the inverted $J$ shape slightly. However, the density distribution of vegetation in open degraded lands has not shown inverted or normal $\mathrm{J}$ shape pattern of distribution due to higher level of disturbance (Fig. 7).

Height classes were divided into four height classes from $0.1-2 \mathrm{~m}$ to $10.1-15 \mathrm{~m}$ classes based on measurement results (Fig. 8). All the seedling, saplings and some of the shrubs less than $2 \mathrm{~m}$ height were recorded in lower height classes in both study habitats. In closed area from the total 2,225 ha-1 woody species, $38 \%$ density of woody species constituted the first height class, $28 \%$ woody species $2-5 \mathrm{~m}$ height class, $21.3 \%$ woody species $5.1-10 \mathrm{~m}$ height class and $12.4 \%$ woody species $10.1-15 \mathrm{~m}$ height classes. Whereas in open woodland from the total $1642 \mathrm{ha}^{-1}$ woody species, $58 \%$ density of woody species constituted the height classes, $38 \%$ woody species $2-5 \mathrm{~m}$ height class, $6.4 \%$ woody species $5.1-10 \mathrm{~m}$ height class and $3.1 \%$ woody species 10.1-15 m height classes. In open degraded land from the total $297 \mathrm{ha}^{-1}$ woody species $59.6 \%$ density of woody species constituted the first height class, $26.3 \%$ woody species $2-5 \mathrm{~m}$ height class, $10 \%$ woody species $5.1-10 \mathrm{~m}$ height class and $4 \%$ woody species $10.1-15 \mathrm{~m}$ height classes.

The tree height analysis result has shown that the density of woody species in closed area constituted the highest density distribution from other habitats and in all height classes except 0.1 to $2 \mathrm{~m}$ class (Fig. 8). The tree height percentage density distribution decreased with an increase in height class showing inverted $\mathrm{J}$ shape pattern of distribution in closed area. Open woodland has shown the highest number of density per ha in the lowest height class only. However, open woodland higher height class from 5.1-15m trees distribution has shown much declined density and significantly affected by disturbance. This shows illegal cutting of tree affected open woodland which affect seed bearing woody species and future regeneration at risk. This has indicated closed area development and management enhancing woody species regeneration and important means of solution for rehabilitation of degraded vegetation (Fig. 8).

\subsubsection{Woody vegetation crown cover classes}

In this study the horizontal crown distribution covered the surface of closed area to reduce erosion and vegetation degradation. Woody vegetation cover reduced the rain drop impact on soil as well as the velocity of erosion. The litter fall in the surface was decomposed and added nutrient to the soil which increases the regeneration of species and enhance succession. Seven crown cover classes prepared and crown cover of horizontal surface by woody species data collected by format absent or less than $1 \%$ cover, 1 to $5 \%$ cover, 6 to $10 \%$ cover, 11 to $25 \%$ cover, 26 to $50 \%$ cover, 51 to $75 \%$ cover and 76 to $100 \%$ cover classes used and data collected from each habitat of study sites. 
Table 7

Crown cover of woody species in the study habitats.

\begin{tabular}{|lllllll|}
\hline Plot & $\begin{array}{l}\text { Plot } \\
\text { size }\end{array}$ & \multicolumn{2}{l}{$\begin{array}{l}\text { Percent cover class in } \\
\text { closed area }\end{array}$} & $\begin{array}{l}\text { Percent cover class in } \\
\text { open woodland }\end{array}$ & \multicolumn{2}{l}{$\begin{array}{l}\text { Percent cover class in open } \\
\text { degraded land }\end{array}$} \\
\cline { 2 - 5 } & Minimum & Maximum & Minimum & Maximum & Minimum & Maximum \\
\hline
\end{tabular}

\begin{tabular}{|llllllll|}
\hline 1 & $400 \mathrm{~m}^{2}$ & 11 & 25 & 51 & 75 & 6 & 10 \\
\hline 2 & $400 \mathrm{~m}^{2}$ & 26 & 50 & 11 & 25 & 6 & 10 \\
\hline 3 & $400 \mathrm{~m}^{2}$ & 26 & 50 & 11 & 25 & 6 & 10 \\
\hline 4 & $400 \mathrm{~m}^{2}$ & 26 & 50 & 26 & 50 & 6 & 10 \\
\hline 5 & $400 \mathrm{~m}^{2}$ & 26 & 50 & 26 & 50 & 6 & 10 \\
\hline 7 & $400 \mathrm{~m}^{2}$ & 11 & 25 & 26 & 50 & 6 & \\
\hline 8 & $400 \mathrm{~m}^{2}$ & 26 & 50 & 11 & 25 & & \\
\hline 9 & $400 \mathrm{~m}^{2}$ & 11 & 25 & 11 & 26 & & \\
\hline 10 & $400 \mathrm{~m}^{2}$ & 26 & 50 & 11 & 26 & & \\
\hline 11 & $400 \mathrm{~m}^{2}$ & 51 & 76 & 11 & 26 & & \\
\hline 12 & $400 \mathrm{~m}^{2}$ & 26 & 50 & 26 & 50 & 60 \\
\hline
\end{tabular}

The crown cover analysis has shown that closed area was the highest crown cover than open woodland and open land area. The minimum and maximum crown covered averaged has 24.3 to $46 \%, 20.6$ to $39.8 \% 6$ to $10 \%$ crown covered in closed area, open woodland and open degraded land, respectively. The effect of closed area enhanced cover class compared with open land four times higher (Table 7). This is because of lesser disturbance to closed area from interference of human and livestock which facilitated regeneration and growth of woody species.

\section{Conclusion And Recommendations}

\subsection{Conclusion}


The research was conducted in Zima Waruma site of Loma Bossa district in Dawuro zone, Southern Ethiopia with the aim of understanding the effect of closed area on woody species regeneration through field vegetation assessment of woody species and comparing among closed area, open Combretum-Terminalia woodland area and open degraded land in the study site.

The results of this study showed that closed area had the highest woody species compositions, richness, density per ha, woody species regeneration, and crown cover percentage than open Combretum-Terminalia woodland area and open degraded land. Closed area showed low evenness and the highest woody species composition similarity. The closed area had shown the higher Simpson's and Shannon Weiner Diversity Index value than open degraded land area. The density of saplings and trees/shrubs composition in closed area significantly exceeds the density of their counterparts in open woodland and degraded land. Closed area showed the highest woody regeneration than corresponding open woodlands and degraded land. This indicated closing area development could enhance woody species diversity than open degraded area. The DBH and height class in closed area had shown the highest density distribution of woody species among other habitats in all DBH class except the first class. Closed area showed inverted $\mathrm{J}$ shape pattern of woody species distribution in both $\mathrm{DBH}$ and height class. It also showed highest crown cover percentage among all of the habitats in this study.

\subsection{Recommendations}

Closed area should be one of the development options to solve the land and woody vegetation degradation in the study site. The effect of closed area on woody species regeneration enhanced natural regeneration, woody species composition and richness compared to other habitats in study area. As a result, closed area development and conservation options should be practiced at similar agro-ecological zones to sustainably manage, utilize vegetation resource in general and conserve the endangered woodland area species in particular. As a result, additional plantation with indigenous and fast-growing species, integrating soil and water conservation, water harvesting trenches and micro-basin should be introduced to improve the natural regeneration status and maximize diversity of woody species. Plantation of fast- growing multipurpose tree and shrubs, agroforestry in homestead area for household energy, construction material and forage should be considered for future sustainability of closed area for more success of regeneration.

Finally, further detailed study is needed on the effect of closed area on soil environment and soil seed bank, water shade development, wildlife, sustainable use of wood and non-wood products from closed area, as well as ethno-botanical value and different uses of regenerated woody species in closed area.

\section{Declarations}

\section{Ethics approval and consent to participate}

Authors declare that there is no information related with an experiment on humans and/or the use of human tissue samples in this paper. Plant woody species data were collected from filed following agreed consent with Dawuro zone and Loma Bosa district agriculture and natural resource offices. 
Authors give permission to publisher to publish data, results and images included in the manuscript.

\section{Availability of data and material}

The datasets used and analyzed during the current study are available from the corresponding author on reasonable request.

\section{Competing interests}

The authors declare that they have no conflict of interest.

\section{Funding}

The authors received no funding for this work.

\section{Authors' contributions}

Both authors equally contributed in this study from data collection up to manuscript preparation.

\section{Acknowledgements}

We are grateful to the Dawuro zone and Lomd Bosa Woreda Agriculture and rural Development office. for permission to conduct research in Lomd Bosa Woreda. We are greatly indebted to many experts and field assistants who have contributed to data collection.

\section{References}

Abebe, T., D. H. Feyssa and E. Kissi. 2014. Area Enclosure as a Strategy to Restore Soil Fertility Status in Degraded Land in Southern Ethiopia. Journal of Biological and Chemical Research 31 (1): $482-494$

Asmare, T.M., \& Gure, A. (2019). Effect of exclosure on woody species diversity and population structure in comparison with adjacent open grazing land: the case of Jabi Tehnan district north western Ethiopia, Ecosystem Health and Sustainability, 5:1, 98-109, DOI: 10.1080/20964129.2019.1593794

Barnes et al., (1998). Barnes, B.V., Zak, D.R., Denton, S.R., Spurr, S.H., 1998. Forest Ecology, 4th ed. Wiley, New York.

Betru N., Jawad A., and Ingrid N., 2005. Exploring ecological and socio-Economic issues for the improvement of area enclosure management: A Case Study from Ethiopia. DCG Report No. 38

Birhane, E. (2002). Actual and Potential Contributions of Enclosures to Enhance Biodiversity in Drylands of Eastern Tigray: With Particular Emphasis on Woody Plants (Doctoral dissertation, Swedish University of Agricultural Sciences).

Blay, D., E. Bonkoungu and B. Chikamai. 2004. Rehabilitation of degraded lands in Sub-Saharan Africa: Lessons learned from selected case studies. Forestry Research Network for SSA. International Union of 
FAO (2008).Land degradation on the rise-One fourth of the world's population affected, says new study. http://www.fao.org/newsroom/en/news/2008/1000874/index.html

FAO (2015). Global Forest Resources Assessment Report 2015. http://www.fao.org/3/a-i4808e.pdf

Gashaw, T., Bantider, A., \& G/Silassie, H. (2018). Land Degradation in Ethiopia: Causes, Impacts and Rehabilitation Techniques. Journal of Environment and Earth Science, Vol.4, No.9, 201.

Giday, K. 2002. Woody biomass estimation in community managed closed areas in Tigray: Implications to sustainable management and utilization. Uppsala, Sweden: Swedish University of Agricultural Sciences.

Kasim, M., Assfaw, Z., Derero, A., Melkato, M., \& Mamo, Y. (2015). The Role of Area Closure On The Recovery Of Woody Species Composition On Degraded Lands And Its Socio-Economic Importance In Central Rift Valley Area, Ethiopia. International Journal of Development Research Vol. 5, No. 02, pp. 3348-3358.

Kebrom, T. 1998. Ecological Rehabilitation of Degraded Hill slopes in South Wello, Ethiopia. Doctoral dissertation, Ph. D. Dissertation, Acta Universitatis Uppsaliensis, Uppsala, 363.

Krebs, C.J. 1999. Ecological methodology (2nd Ed.). University of British Colombia, Harper Collins, New York.

Le, Q., B., Nkonya, E. M., \& Mirzabaev, A. (2016). Biomass productivity-based mapping of global land degradation hotspots. In Economics of land degradation and improvement- A global assessment for sustainable development, ed. Ephraim Nkonya, Alisher Mirzabaev, and Joachim von Braun. Chapter 4, pp. 55 84. http://dx.doi.org/10.1007/978-3-319-19168-3_4

Manaye, A., Negash, M., \& Alebachew, M. (2019). Effect of degraded land rehabilitation on carbon stocks and biodiversity in semi-arid region of Northern Ethiopia. Forest Science and Technology, 15:2, 70-79, DOI: 10.1080/21580103.2019.1592787

Megerssa, R. G., \& Bekere, B. Y. (2019). Causes, consequences and coping strategies of land degradation: evidence from Ethiopia. Journal of Degraded and Mining Lands Management, Vol 7, No 1, 1953-1957.

Mekuria, W., Aynekulu, E. (2013). Exclosure land management for restoration of the soils in degraded communal grazing lands in northern Ethiopia. Land Degrad. Dev. 24, 528e538.

Mekuria W, Langan S, Noble A, Johnston R. (2017). Soil restoration after seven years of exclosure management in Northwestern Ethiopia. Land Degrad Develop. 28(4):1287-1297.

Mekuria, W., Wondie, M., Amare, T., Wubet, A., Feyisa, T., and Yitaferu, B. (2018). Restoration of degraded landscapes for ecosystem services in North-Western Ethiopia. Heliyon 4 (2018) e00764. doi:

10.1016/j.heliyon.2018. e00764

Mganga KZ, Musimba NKR, Nyariki DM. (2015). Combining sustainable land management technologies to combat land degradation and improve rural livelihoods in semi-arid lands in Kenya. Environ Manag. 56(6):1538-1548. 
Mureithi, S. M., Verdoodt, A., Gachene, C. K., Njoka, J. T., Wasonga, V. O., De Neve, S., ... Van Ranst, E. (2014). Impact of enclosure management on soil properties and microbial biomass in a restored semi-arid rangeland, Kenya. Journal of Arid Land, 6(5), 561-570.

Nedessa, B., J. Ali, J., \& Nyborg, I. (2005). Exploring ecological and socio-economic issues for the improvement of area enclosure management. A case study from Ethiopia. Dry lands Coordination Group, Miljøhuset G, 9.

Nkonya E., Johnson T., Kwon H.Y., Kato E. (2016) Economics of Land Degradation in Sub-Saharan Africa. In: Nkonya E., Mirzabaev A., von Braun J. (eds) Economics of Land Degradation and Improvement - A Global Assessment for Sustainable Development. Springer, Cham

Reside AE, VanDerWal J, Moran C. (2017). Trade-offs in carbon storage and biodiversity conservation under climate change reveal risk to endemic species. Biol Conserv. 207:9-16.

Seid, M., Desta, A. B., \& Zewdu, T. (2020). Effect of range land vegetation degradation on livestock and socioeconomics status of the pastoralists, Afar regional state, Northern Ethiopia. Journal of Dryland Agriculture , 6(3), 17-27.

Senbeta, F., Teketay, D. \& Näslund, B. (2002) Native woody species regeneration in exotic tree plantations at Munessa-Shashemene Forest, southern Ethiopia. New Forests 24, 131-145.

https://doi.org/10.1023/A:1021201107373

Shannon, C. E. and W. Weiner. 1949. The Mathematical Theory of Communication. Illinois, Chicago. USA.

Shibru, S., and G. Balcha, (2004). Composition, Structure and regeneration status of woody species in Dindin Natural Forest, Southeast Ethiopia: An implication for conservation. Ethiop. J. of Biol. Sci. 1(3): 15-35.

Simpson, E. (1949). Measurement of Diversity. Nature 163, 688. https://doi.org/10.1038/163688a0

SNNPRS-BoFED. 2004. Regional atlas. Southern Nation, Nationalities and Peoples Regional State, Bureau of Finance and Economic Development, Bureau of Statistics and Population, Awassa, Ethiopia. [19]

Taddese, G. (2001). Land degradation: a challenge to Ethiopia. Environ Manage. 2001;27(6):815-824. doi:10.1007/s002670010190

Teketay, D. 1997. Seedling populations and regeneration of woody species in dry Afromontane forests of Ethiopia. Forest Ecology and Management 98 (2): 149-165.

Teketay, D., Kashe, K., Madome, J. et al. (2018). Enhancement of diversity, stand structure and regeneration of woody species through area exclosure: the case of a mopane woodland in northern Botswana. Ecol Process 7, 5 (2018). https://doi.org/10.1186/s13717-018-0116-x

Wolka, K., A. Moges and F. Yimer. 2013. Farmers' perception of the effects of soil and water conservation structures on crop production: The case of Bokole watershed, Southern Ethiopia. African Journal of 
Yirdaw E, Tigabu M, Monge Monge AA. (2017). Rehabilitation of degraded dryland ecosystems - review. Silva Fenn. 51(1):1-32.

\section{Figures}

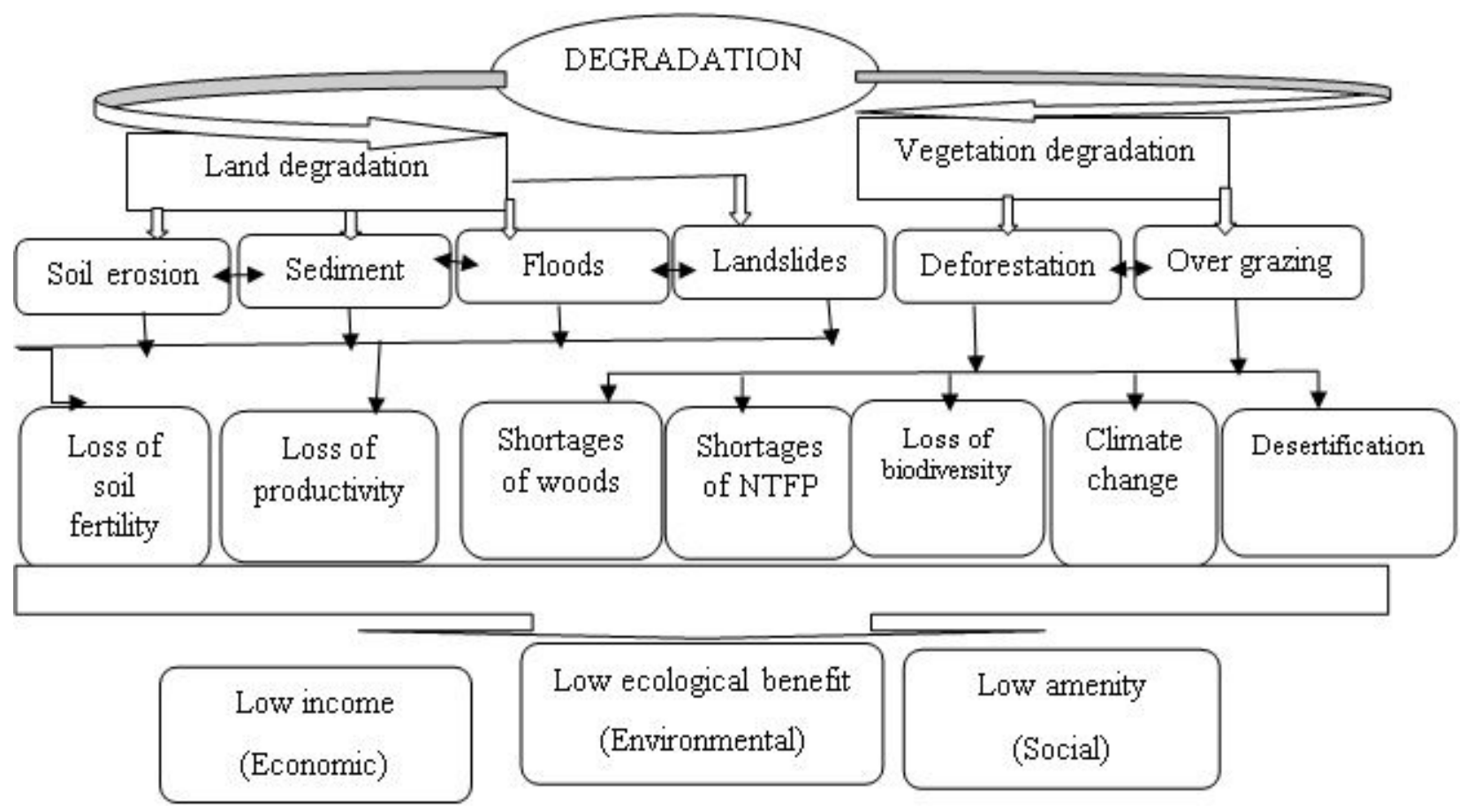

\section{Figure 1}

The diagram representation of main causes and consequences of land degradation. 


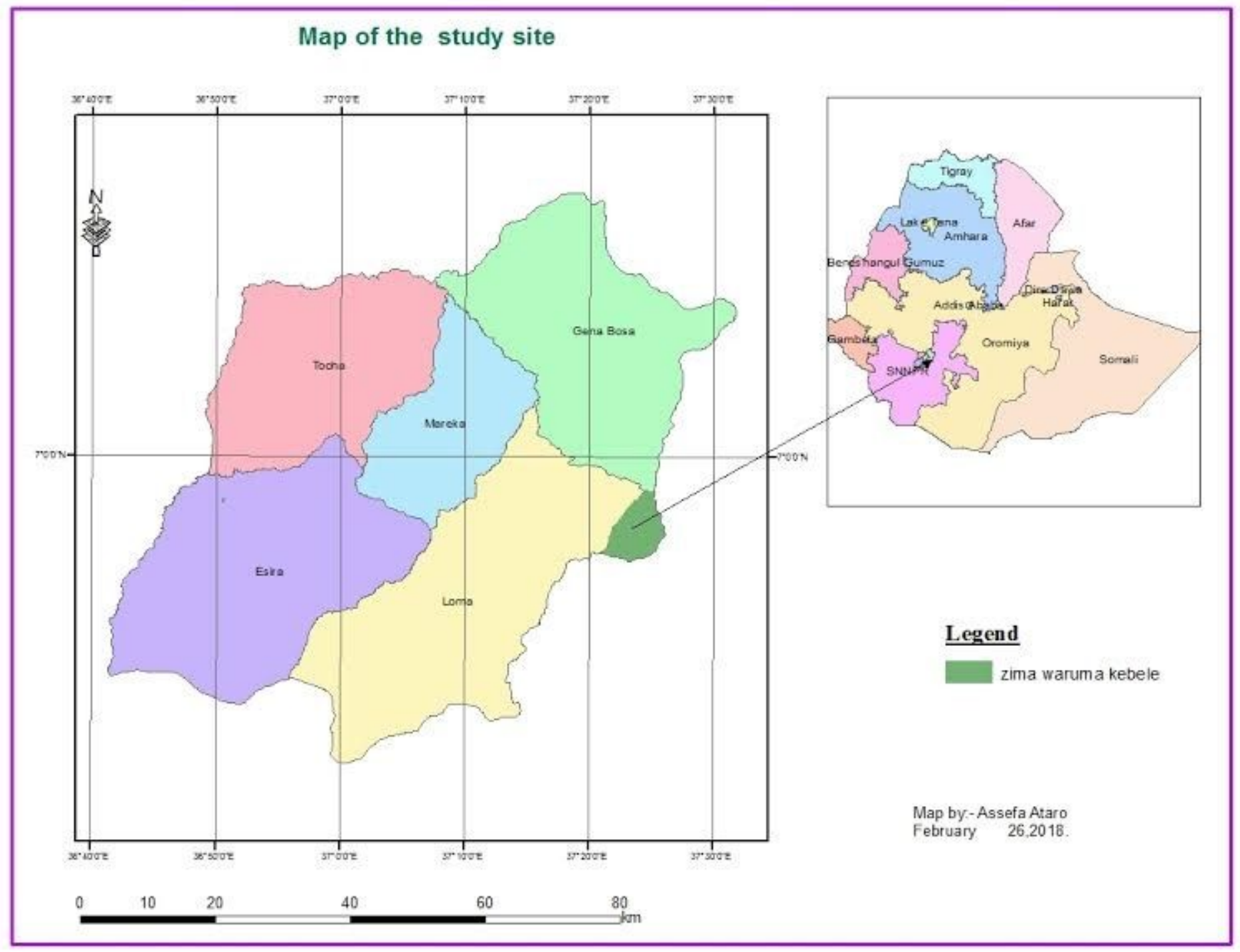

Figure 2

Administrative map of Zima Waruma kebele in Loma Bosa district of Dawuro Zone; SNNPRS, Ethiopia. 


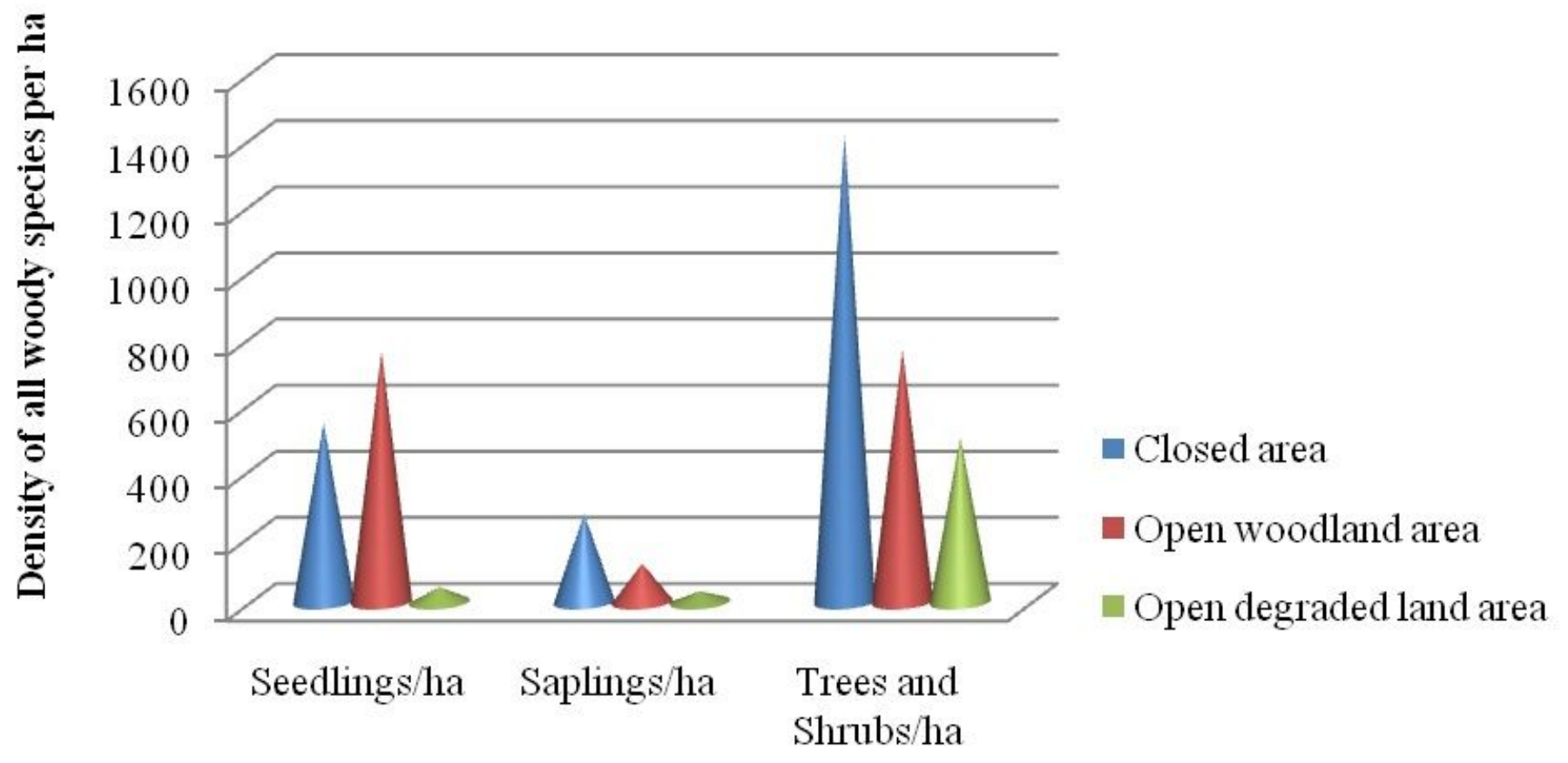

\section{Life forms between habitats}

\section{Figure 3}

Regeneration of seedlings, saplings and trees/shrubs in closed area, open woodland area and open degraded land area. 


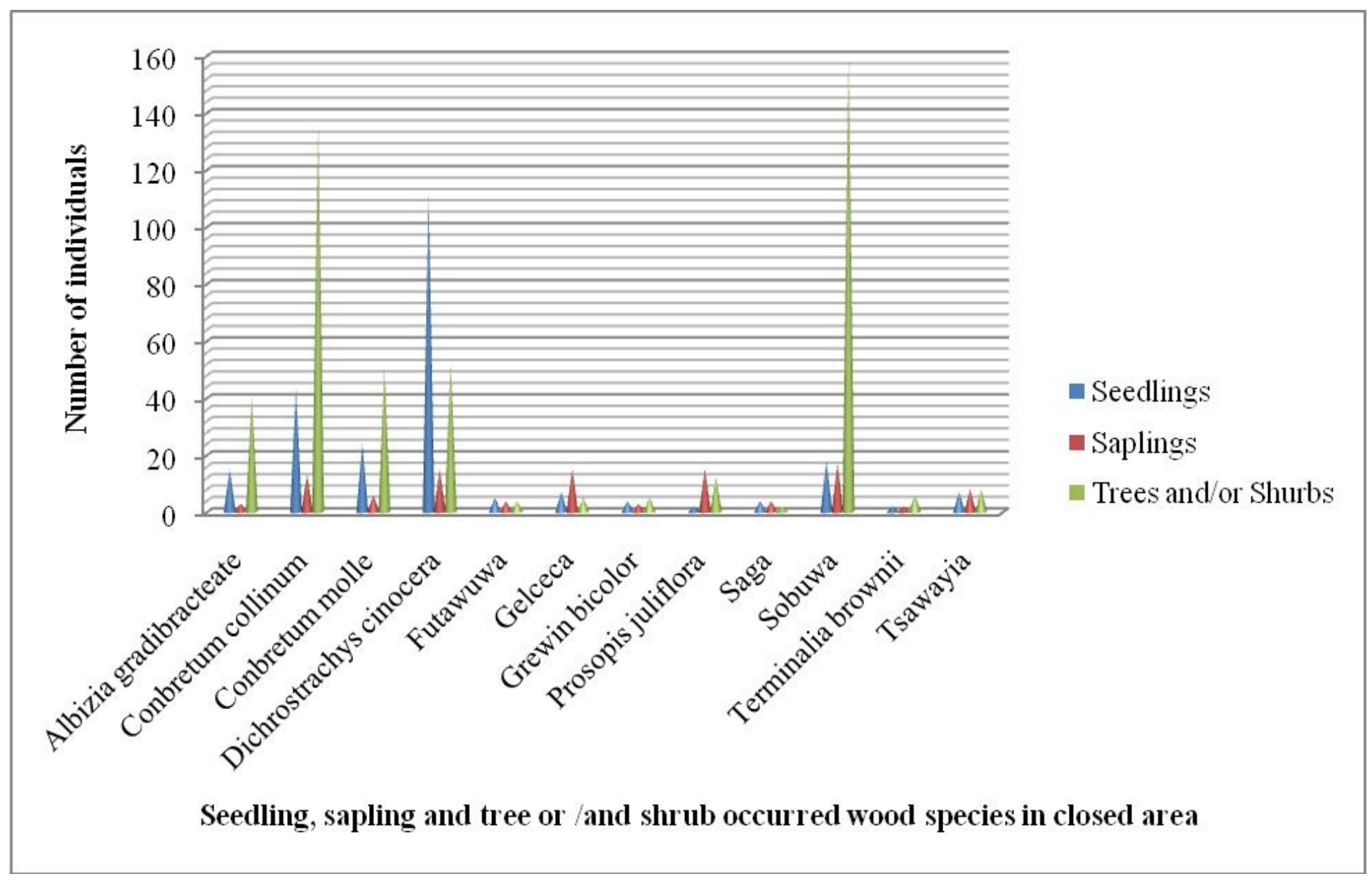

\section{Figure 4}

Regeneration of individual woody species that showed seedlings, saplings and trees/shrubs in closed area. 


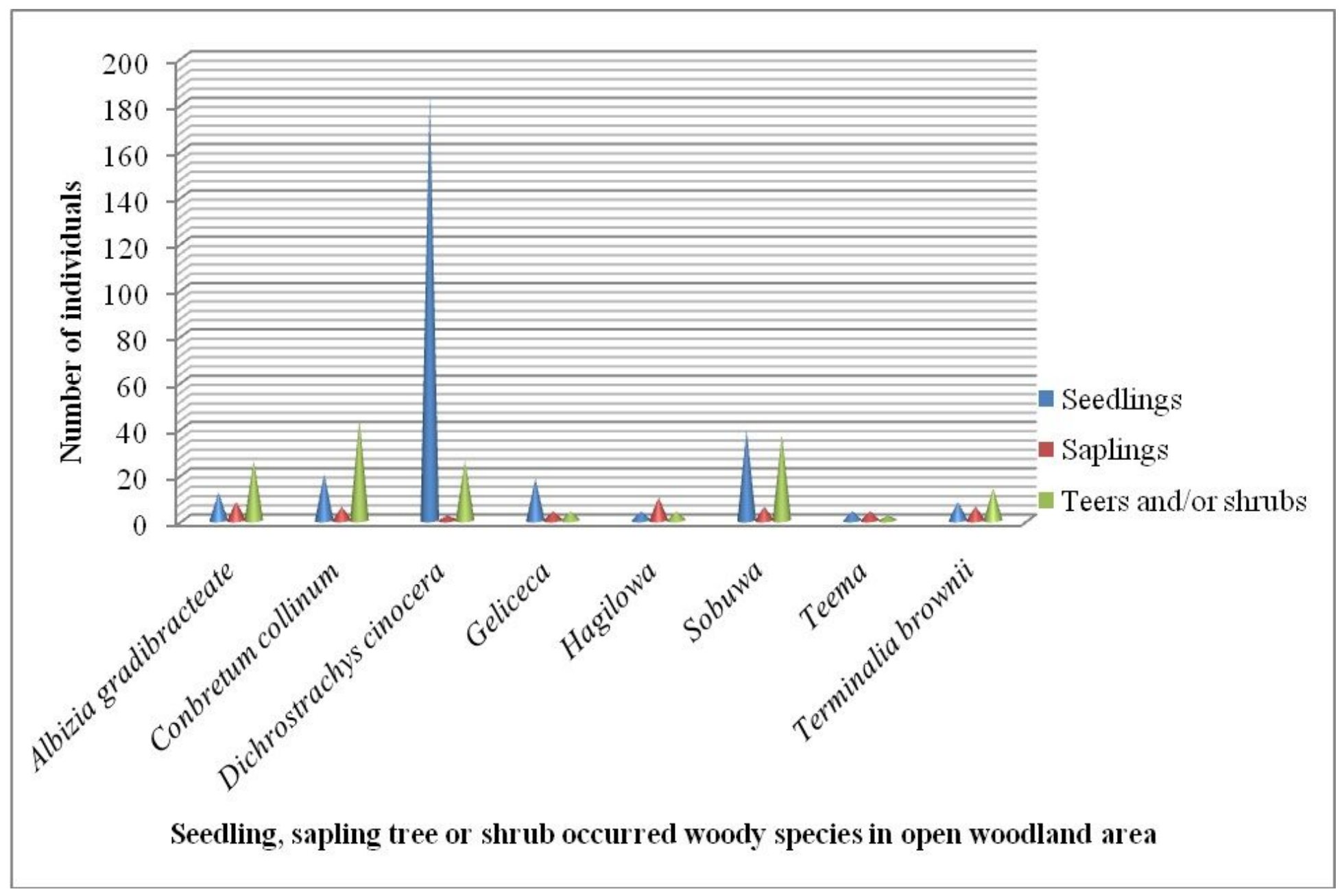

Figure 5

Regeneration of individual woody species that showed seedlings, saplings and trees/shrubs in open woodland area.

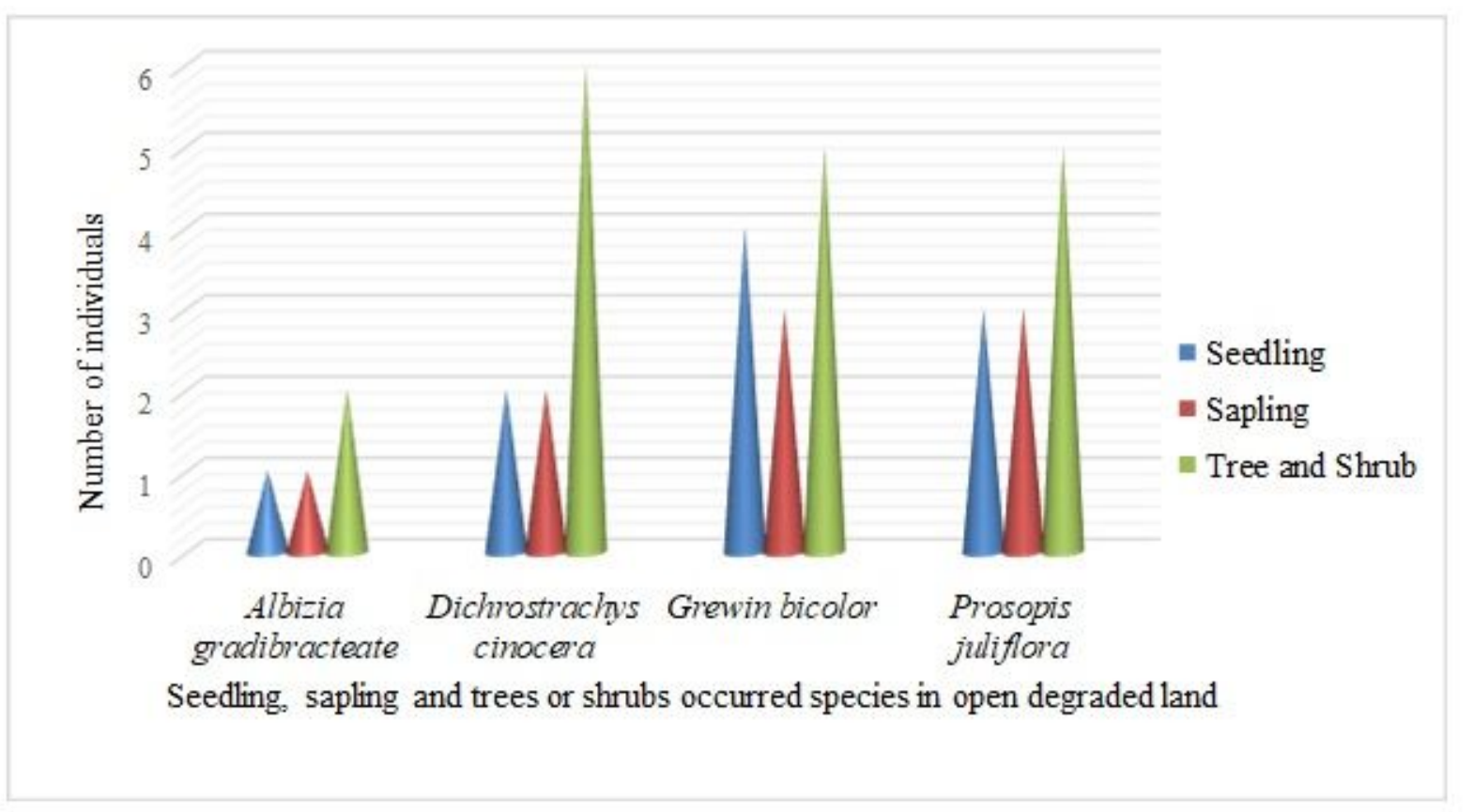


Figure 6

Regeneration of individual woody species that showed seedlings, saplings and trees/shrubs in open degraded land area.

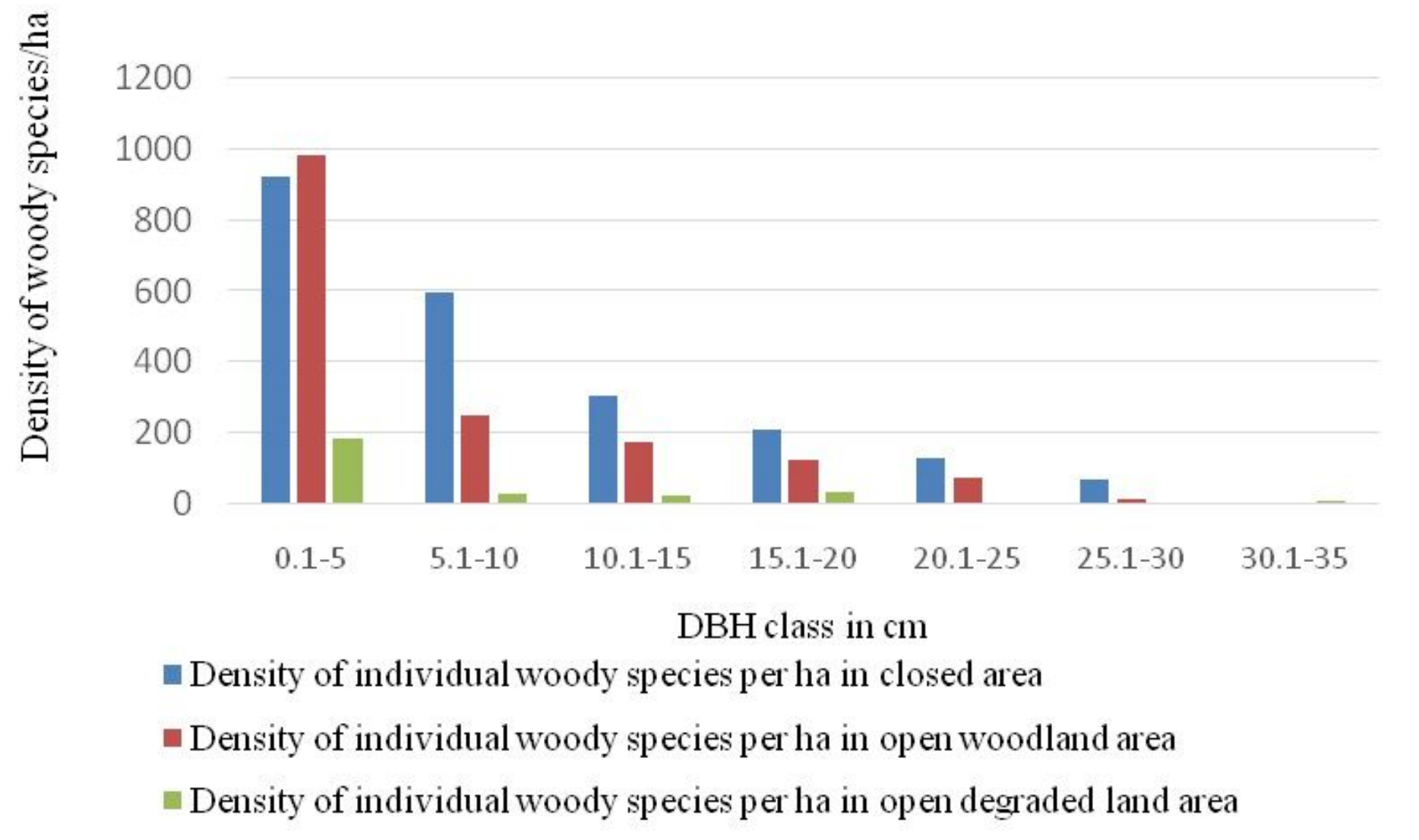

Figure 7

Density of woody species by DBH class in the study habitats 


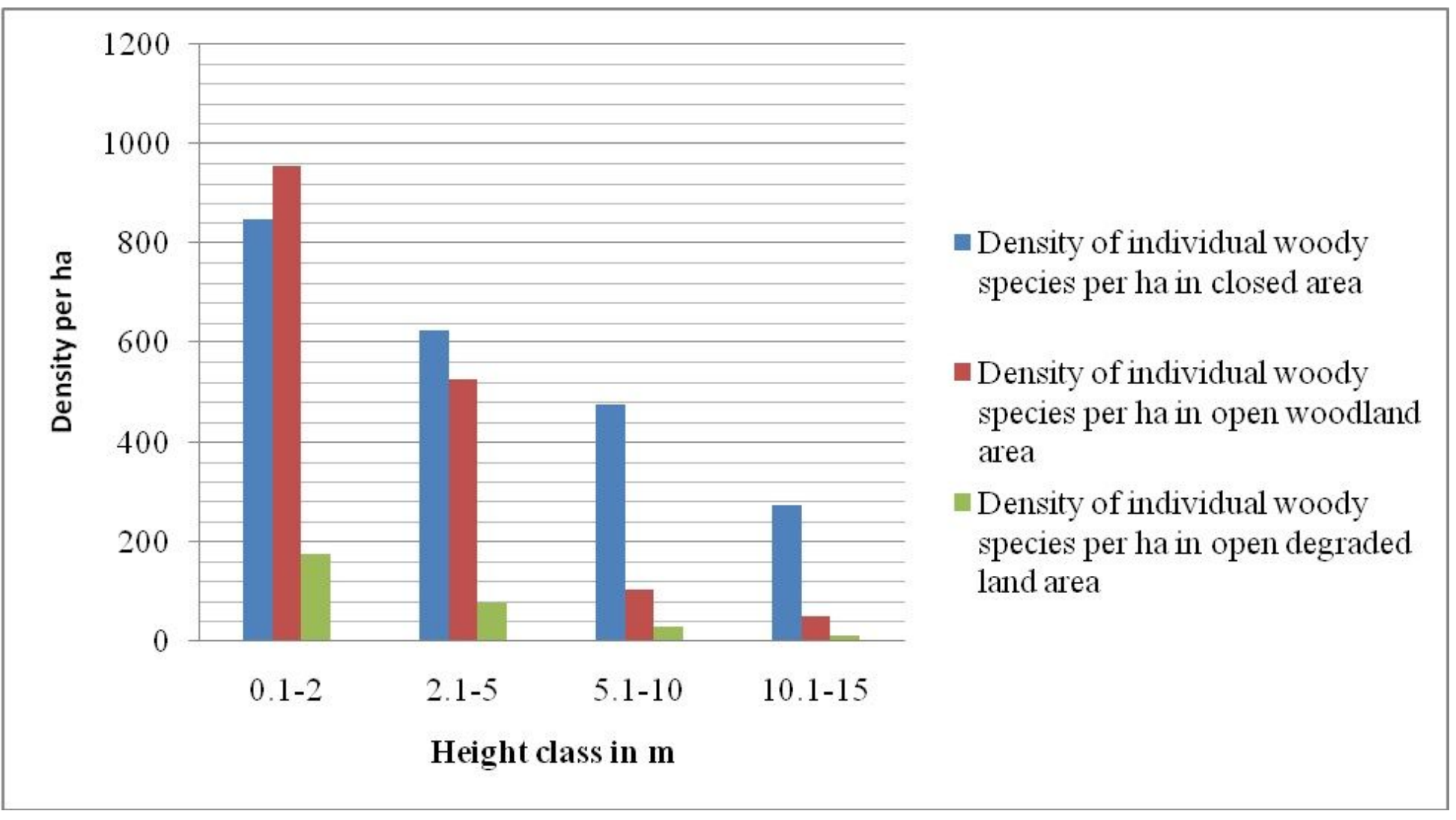

\section{Figure 8}

Density of woody species by height class distribution in the study habitats 